\title{
The pilot study of radiology nursing intervention in abdominal 3-T Magnetic Resonance examination
}

\author{
Estudo piloto sobre a intervenção de enfermagem na radiologia \\ em exame de Ressonância Magnética abdominal 3 Tesla \\ Estudio piloto de intervención de enfermería radiológica \\ en examen de Resonancia Magnética 3-T
}

Gui-qing Dong1, Wen-wen Wang², Kai Deng1, Guang-li Wang1

Ho to cite this article:

Dong GQ, Wang WW, Deng K, Wang GL. The pilot study of radiology nursing intervention in abdominal 3-T Magnetic Resonance examination. Rev Esc Enferm USP. 2016;50(6):959-962. DOI: http://dx.doi.org/10.1590/S0080-623420160000700012

${ }^{1}$ Shandong University, Qianfoshan Hospital Affiliated, CT-MR Division, Jinan, Shandong Province, P. R. China.

${ }^{2}$ Shandong Medical Imaging Research Institute, 2. CT Department, Jinan, Shandong Province, P. R. China.

\begin{abstract}
Objective: The aim of this study was to investigate the effect of radiology nursing intervention in abdominal examination at 3-T MRI. Method: 60 patients with abdominal diseases were divided into two groups randomly: MR nursing intervention group and control group. All the patients underwent abdominal MR examination at 3-T. The MR nursing interventions were performed in nursing intervention group. The outcomes, including one-time success rate, the ratio of diagnosable MR images and the points of image quality, were compared between these two groups. Results: The one-time success rates in control group and MR nursing intervention group were $66.67 \%$ and $96.67 \%$ with significant difference $\left(\chi^{2}=9.017, \mathrm{P}<0.05\right)$. The ratios of diagnosable images in the two groups were $76.67 \%$ and $96.67 \%$ with significant difference $\left(\chi^{2}=5.192, \mathrm{P}<0.05\right)$. The points of MR image quality in the two groups were $1.87 \pm 0.86$ and $2.33 \pm 0.55$, respectively. There was significant difference between these two groups $(t=-2.508, \mathrm{P}<0.05)$. Conclusion: The effective nursing intervention can make the patients cooperation better in abdominal MR examination and improve the image quality significantly.
\end{abstract}

\section{DESCRIPTORS}

Magnetic Resonance Imaging; Nursing Care; Radiograpy Abdominal; Quality Improvement. 


\section{INTRODUCTION}

Magnetic resonance imaging (MRI) is a noninvasive diagnostic modality using a magnetic field and radiowaves to image body tissues. Now MRI is widely used in the whole body imaging for its high soft tissue resolution and nonradiating procedure ${ }^{(1)}$. In the imaging of abdomen examination, MRI is more sensitive than CT in many diseases' diagnosis and differential diagnosis, such as liver tumors, cystic and fat tissues. Furthermore, MRI can produce high quality images at any angle and construct three-dimensional images. It can differentiate between tissues of similar nature. However, MRI also has some limitations. Safety is an extremely important factor in MRI. There is no radiation danger, but the magnet is extremely powerful. Before going into the magnet room, every patient must remove any ferromagnetic objects which are greatly affected by the strong magnetic. Moreover, patients often find the procedure claustrophobic and noisy in the examination which can make them feel terrified, especially in ultrahigh field 3-T MR systems. And the respiration usually makes the abdominal images fuzzy. Radiology nursing is a relatively new field ${ }^{(2)}$.Nurses can provide care and teaching to patients, especially to the patients who undergo MR examination for the first time. Through nursing intervention, patients maybe complete MR examination more comfortably and the artifacts of images will be extremely removed. But only few studies focused on the effect of radiology nursing in the literatures ${ }^{(3-5)}$. This study explored the effect of radiology nursing intervention in abdominal MR examination at 3-T which has been widely used in clinic. From this study, the medical students and clinical doctors may understand more about the radiology nursing.

The aim of this study was to investigate the effect of radiology nursing intervention in abdominal examination at 3-T MR. The population included 60 adult patients in abdominal examination by magnet resonance. MR nursing interventions were evaluated, compared with usual care. And the outcomes included success rate of MR examination and quality of MR image.

\section{METHOD}

\section{Gieneral information}

This study was performed under an institutional review board protocol and complied with the Declaration of Helsinki. From January 2013 to July 2014, 60 patients who had known or probable abdomen diseases underwent assessment with MR of the abdomen. They were 24 males and 36 females (age range, 38-69 years; mean age, 56.2 years). The patients were divided into two groups randomly: MR nursing intervention group and control group. For the randomization process, we used Random number table and Random number remainder grouping method. This method could ensure the randomization and balance of grouping. Informed consents were obtained from all patients before MR examination.

MR imaging was performed using a 3-T MR system (Siemens Magnetom Skyra 3-T) with an 8-channal torso phased-array coil. Routine abdominal MR images were acquired as follows: T2-weighted imaging in the coronal plane, T2-weighted imaging in the axial plane with fat saturation, T1-weighted imaging in the axial plane, T2-weighted imaging in the axial plane and diffusion weighted imaging in the axial plane.

\section{Procedures}

In control group, patients were only informed to read the announcements for MR examination carefully and signed the confirmation. Then they waited for the examination. All of objects which could influence the magnetic field must be removed before examination and the patients left MRI room by themselves after examination.

In MR nursing intervention group, the whole nursing interventions were performed. That means nursing intervention was performed in each period from arrival to MRI room to finish of examination, including pre-, in and post-examination period. For each patient, the whole nursing interventions were performed by the same radiology nurse who had experience of radiology nursing for more than ten years.

\section{NURSING INTERVENTION IN PRE-EXAMINATION PERIOD}

Radiology nurse firstly told the patients and their relatives the matters needing attention for MR examination in detail. Before examination, the nurse led the patients to the gate of MR scanning room and made the patients understand the procedure and noisy emitted by the MR machine. And then the nurse simply introduced the MR principle, safety and probable discomfort to eliminate the patients' doubt and intense emotion fear.

\section{NURSING INTERVENTION IN EXAMINATION PERIOD}

Before entering the MR scanning room, the nurse and technologist checked the patients' general information again carefully and ensured no ferromagnetic objects. Then the nurse trained the patient's respiration in examination patiently. The respiration training was very important. The patients were reminded to breathe regularly and slowly and hold their breath about 15-20s when they listened to the respiratory order every time. In each time, the respiration should be tried to make the same level in order to ensure the consistency of the scanning level. During the examination, the nurse observed the patients closely and carefully until the end of scan.

\section{NURSING INTERVENTION IN POST-EXAMINATION PERIOD}

After the examination, the nurse asked and placated the feeling of the patients, encouraged them to face the proper results with good mentality. If enhanced scan was needed for further examination, the nurse would lead the patient to therapeutic room for next step.

\section{The eVAluation of MR IMAGeS}

An experienced radiologist and a senior radiologic technologist differentiated and analyzed the MR images together. Image quality was measured a four-point scale: (1) 0 point, abdominal organs were displayed unclearly with image distorted significantly; (2) 1 point, abdominal organs 
were displayed fuzzy with image distorted partly, unable to diagnose; (3) 2 points, abdominal organs were displayed fairly with image distorted slightly, without affecting diagnosis; (4) 3 points, abdominal organs were displayed clearly with no image distorted. The latter two results considered diagnostically adequate. Only obtained diagnosable images, MR examination could be considered successful.

\section{Statistical ANALYSIS}

Statistical analysis was done on SPSS 19.0 software. The success rate and the ratio of diagnosable images were calculated by chi-square test.between two groups. The independent samples $\mathrm{T}$ test was used to evaluate the points of image quality between two groups. $\mathrm{P}<0.05$ was considered statistically significant.

\section{RESULTS}

\section{THE CHARACTERISTICS OF PATIENTS}

Each group contained 30 patients. The characteristics of patients in these two groups were shown in Table 1. There was no significant difference for general information between these two groups.

Table 1 - The characteristics of patients-Jinan, Shandong Province, China, January 2013 to July 2014.

\begin{tabular}{lcc}
\hline Variable & Nursing intervention group & Control group \\
\hline Age (years) & & \\
Mean [age(SD)] & $53.3(8.75)$ & $57.2(8.96)$ \\
Range & $38-68$ & $40-69$ \\
Sex [n(\%)] & & \\
Male & $11(36.7)$ & $13(43.3)$ \\
Female & $19(63.3)$ & $17(56.7)$ \\
\hline
\end{tabular}

The success rate of MR examination

20 patients completed MR examination at a time in control group while 29 patients in MR nursing intervention group. The one-time success rates in the two groups were $66.77 \%$ and $96.67 \%$, respectively. There was significant difference between the two groups $\left(\chi^{2}=9.017, P<0.05\right)$.

\section{THE IMAGE QUALITY}

The outcomes of image quality were showed in Table 2. The ratios of diagnosable images in control group and MR nursing intervention group were $76.67 \%$ and $96.67 \%$. There was significant difference between the two groups $\left(\chi^{2}=5.192, \mathrm{P}<0.05\right)$. The average points of image quality were $1.87 \pm 0.86$ and $2.33 \pm 0.55$, respectively. There was significant difference between the two groups $(\mathrm{t}=-2.508, \mathrm{P}<0.05)$.

Table 2 - Score of MR image quality-Jinan, Shandong Province, China, January 2013 to July 2014.

\begin{tabular}{|c|c|c|c|c|c|c|c|}
\hline \multirow{2}{*}{ Variable } & \multirow{2}{*}{$\mathbf{n}$} & \multicolumn{4}{|c|}{ point } & \multirow{2}{*}{$\begin{array}{c}\text { The ratio of } \\
\text { diagnosable } \\
\text { images }(3+2) \%\end{array}$} & \multirow{2}{*}{$\begin{array}{l}\text { Average point } \\
\text { [mean(SD)] }\end{array}$} \\
\hline & & 3 & 2 & 1 & $\mathbf{0}$ & & \\
\hline Control group & 30 & 6 & 17 & 4 & 3 & 76.67 & $1.87(0.86)$ \\
\hline $\begin{array}{c}\text { Nursing } \\
\text { intervention group }\end{array}$ & 30 & 11 & 18 & 1 & 0 & 96.67 & $2.33(0.55)$ \\
\hline
\end{tabular}

\section{DISCUSION}

As we know, radiology imaging modalities, including $\mathrm{X}$-ray, computed tomography (CT), magnetic resonance imaging (MRI), ultrasound (US), nuclear medicine, interventional radiology and mammography, are widely used in routine clinical work. They are extremely valuable tools used in the diagnostic of disease and altered health states. The goal of radiology imaging is to provide high quality images with minimum discomfort to the patient. Radiology nurses play an important role in achieving this goal by working in collaboration with the radiologist and the radiologic technologist ${ }^{(6)}$.

Radiology nursing is a relatively new field in which nurses can use multiple skills in caring for adult and pediatric patients. The nursing interventions in radiology department usually include awareness of imaging technique, informing and preparing patients, safety, communication with patients and radiology staff. MRI is also a relative new radiology imaging modality compared with the other imaging modalities. MR images of diagnostic quality were firstly published in 1980 and since then have been rapidly developing ${ }^{(7)}$. Maybe many people don't know the examination clearly. Contraindications for MR examination include pacemakers, implants, defibrillators, cerebral aneurysm, or metal in eyes. And the noisy and claustrophobia maybe cause uncomfortable, even terrified to patient so that they will abandon the scan. The radiology nurses provide care, teaching and education to patients to eliminate their anxiety and fear ${ }^{(8)}$. Our procedures in this study included the introduction of MRI basic knowledge, adaptation in the environment before MR scan. From these methods of nursing intervention, the patient could finish the examination easily without fear. In our study, the one-time success rate in nursing intervention group was much higher than that in control group.

Respiration training is another key factor which can influence imaging quality of abdominal MR examination ${ }^{(9)}$. Respiration can make the abdominal images blur because of the respiratory movement artifact. So how to control breath during the examination is very important. In our MR nursing intervention, radiology nurse was responsible for patient's respiration training. Radiology nurse taught and guided the patients to breathe regularly and slowly and hold their breath about 15-20s when they listened to the respiratory order every time. In each time, the respiration should be tried to make the same level in order to ensure the consistency of the scanning level. Maybe some old patients understood or cooperated difficultly sometimes. The nurse should be patient until they could control the skills. Thus high quality images would be obtained. In our study, the respiratory movement artifact was significantly reduced in nursing intervention group and the image quality was much higher than that in control group.

The limitation of this study was that the number of cases was small. A larger population of the patients may be required in the future. Another limitation was that we only evaluated the image quality, not involved the disease itself in this study. Maybe some diseases have special situations, and the control of image quality is also different. So further studies should be continued to decide how well radiology nursing intervention would affect the diagnosis of abdominal diseases. 


\section{CONCLUSION}

In conclusion, the radiology nursing intervention in abdominal MR examination can not only ensure the scan going well, but also improve the image quality significantly. It is very important and necessary in routine abdominal MR examination.

\section{RESUMO}

Objetivo: $\mathrm{O}$ objetivo deste estudo foi investigar o resultado da intervenção de enfermagem na radiologia em exame de ressonância magnética (RM) abdominal 3 Tesla. Método: 60 pacientes com patologias abdominais foram aleatoriamente divididos em dois grupos: grupo de intervenção de enfermagem em RM e grupo controle. Todos os pacientes foram submetidos ao exame de RM abdominal 3 Tesla. As intervenções de enfermagem em RM foram realizadas no grupo de intervenção de enfermagem. Os resultados foram comparados entre os dois grupos, incluindo a taxa de sucesso único, o coeficiente das imagens de RM diagnosticáveis e os pontos da qualidade de imagem. Resultados: As taxas de sucesso único no grupo controle e no grupo de intervenção de enfermagem em RM foram $66,67 \%$ e $96,67 \%$, com diferença significativa de $\left(\chi^{2}=9,017, \mathrm{P}<0,05\right)$. Os coeficientes das imagens diagnosticáveis nos dois grupos foram $76,67 \%$ e $96,67 \%$, com diferença significativa de $\left(\chi^{2}=5,192, \mathrm{P}<0,05\right)$. Os pontos da qualidade de imagem da $\mathrm{RM}$ nos dois grupos foram respectivamente $1,87 \pm 0,86$ e $2,33 \pm 0,55$. Houve uma diferença significativa entre estes dois grupos $(t=-2,508, P<0,05)$. Conclusão: A intervenção de enfermagem eficaz pode melhorar a cooperação dos pacientes no exame de RM abdominal e melhorar consideravelmente a qualidade da imagem.

\section{DESCRITORES}

Imagem por Ressonância Magnetica; Cuidados de Enfermagem; Radiografia Abdominal; Melhoria da Qualidade.

\section{RESUMEN}

Objetivo: Se objetivó investigar el efecto de la intervención de enfermería radiológica en examen abdominal de IRM 3-T. Método: Sesenta pacientes con enfermedades abdominales fueron divididos aleatoriamente en dos grupos: grupo intervención de enfermería RM y grupo control. Todos fueron sometidos a examen abdominal de RM 3-T. Las intervenciones de enfermería RM se efectuaron en el grupo establecido. Los resultados, incluyendo tasa de éxito en única vez, relación de imágenes de RM diagnosticables y puntos de calidad de imagen, fueron comparadas entre ambos grupos. Resultados: La tasa de éxito en única vez en grupo control y grupo intervención de enfermería RM fueron de 66,67\% y 96,67\%, expresando diferencias significativas $\left(\chi^{2}=9.017, \mathrm{P}<0.05\right)$. Los puntos de calidad de imagen

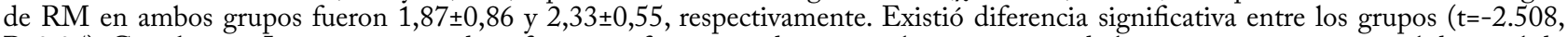
$\mathrm{P}<0.05)$. Conclusión: La intervención de enfermería efectiva puede mejorar la cooperación de los pacientes en examen abdominal de RM y mejorar significativamente la calidad de imagen.

\section{DESCRIPTORES}

Imagen por Resonancia Magnética; Atención de Enfermería; Radiografía Abdominal; Majoramiento de la Calidad.

\section{REFERENCES}

1. Torricelli P1, Ferraresi S, Fiocchi F, Ligabue G, Jasonni VM, Di Monte I, et al. 3-T MRI in the preoperative evaluation of depth of myometrial infiltration in endometrial cancer. AJR Am J Roentgenol. 2008;190(2):489-95.

2. Goodhart J, Page J. Radiology nursing. Orthop Nurs. 2007;26(1):36-9.

3. Zubay RL. Understanding magnetic resonance imaging from a nursing perspective. Orthop Nurs. 1988;7(6):17-23.

4. Johnson LC, Richards TL, Archbold KH, Landis CA. Functional magnetic resonance imaging in nursing research. Biol Res Nurs. 2006;8(1):43-54.

5. Marrs J. Lymphedema and implications for oncology nursing practice. Clin J Oncol Nurs. 2007;11(1):19-21.

6. Malcolm A1. Medical imaging techniques--implications for nursing care. Nurs Stand. 2006;20(41): 46-51.

7. Lester JL, Wessels AL, Jung Y. Oncology nurses' knowledge of survivorship care planning: the need for education. Oncol Nurs Forum. 2014;41(2): E35-43.

8. Kelly K. The changing image of radiology nursing. Can Nurse. 2013;109(2): 26-7.

9. Bluemke DA1, Breiter SN. Sedation procedures in MR imaging safety, effectiveness, and nursing effect on examinations. Radiology. 2000;216(3):645-52.

Financial support: This research was funded by the Scientific and Technological Development Foundation of Shandong Province (grant $n^{\circ}$. 2012YD18060). 